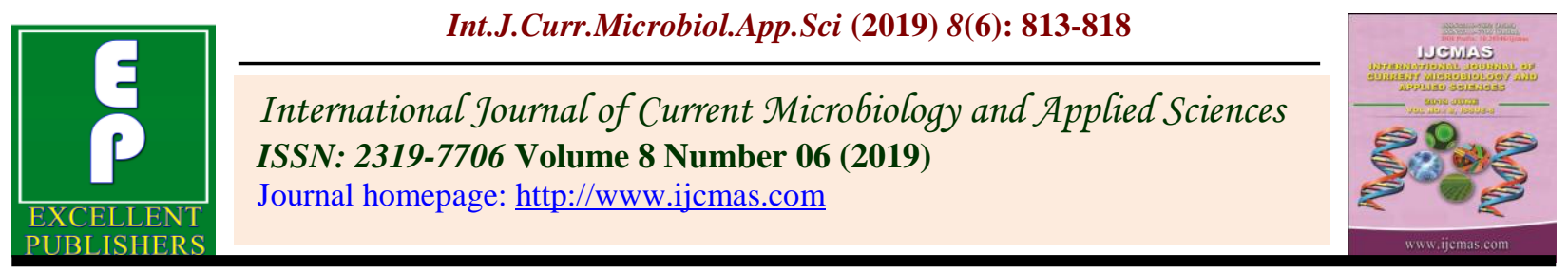

Original Research Article

https://doi.org/10.20546/ijcmas.2019.806.098

\title{
Assessment of Soil pH, EC and OC in Different Land Use Systems of Doda District, J\&K, India
}

\author{
Tajamul Aziz Alaie* and Renu Gupta \\ Division of Soil Science and Agricultural Chemistry, FOA, SKUAST-J, \\ Chatha, Jammu (J\&K), India \\ *Corresponding author
}

\begin{tabular}{l} 
Ke y w o r d s \\
Barren land, \\
$\begin{array}{l}\text { Electrical } \\
\text { Conductivity, IDW, } \\
\text { GIS and Land use } \\
\text { systems }\end{array}$ \\
\hline Article Info \\
\hline $\begin{array}{l}\text { Accepted: } \\
\text { 07 May } 2019 \\
\text { Available Online: } \\
\text { 10 June } 2019\end{array}$ \\
\hline
\end{tabular}

A B S T R A C T
The present study was undertaken to assess the status of soil $\mathrm{pH}, \mathrm{EC}$ and $\mathrm{OC}$ in one hundred and eighty soil samples collected from different land use systems of district Doda. A soil survey was conducted in the month of April, 2016 to assess soil pH, EC and OC. Composite surface soil samples were collected using stratified random sampling method at a depth of 0-15 cm from Agriculture, Barren lands and at a depth of 1 metre from Forest, Horticulture of district Doda. The exact sample location was recorded using a handheld GPS receiver. Geographic Information System (GIS) and Inverse distance weighting (IDW) technique was adopted to generate prediction maps of these soil properties. Soil $\mathrm{pH}$ was moderately acidic to slightly alkaline, EC was $(<1 \mathrm{dS} / \mathrm{m})$ indicated non-saline condition which is safe for plant growth and development. Organic carbon content was moderate to high ranged from $(0.5-1.00 \%)$. Maximum soil $\mathrm{pH}$ was recorded under barren land (7.90) followed by agriculture (7.55), horticulture (7.30) and forest (7.21). The Electrical Conductivity under different land use systems ranged from $0.08-0.31 \mathrm{~d} \mathrm{~S} \mathrm{~m}^{-1}$ under forest, 0.18-0.77 $\mathrm{d} \mathrm{S} \mathrm{m}^{-1}$ under barren land, 0.11-0.45 $\mathrm{d} \mathrm{S} \mathrm{m}^{-1}$ under agriculture and $0.10-0.35 \mathrm{~d} \mathrm{~S} \mathrm{~m}^{-1}$ under horticulture, respectively. The maximum OC was recorded under forest $(1.19 \%)$, followed by horticulture $(0.97 \%)$, agriculture $(0.87 \%)$ and barren land $(0.65 \%)$.

\section{Introduction}

Soil is a vital natural resource which should be used judiciously according to its potential to meet the increasing demands of ever growing population. To ensure optimum agricultural production, it is imperative to know best fact about our soils and their management to achieve sustainable production. The quality of soil needs to be looked into because presently the natural resources are being over exploited. Scientific information concerning spatial variability and distribution of soil properties is critical for farmers attempting to increase efficiency of fertilizers and crop productivity (Mabit et al., 2008; Tesfahunegn et al., 2011). Fertilization based on maps with recommendations related to soil fertility may also lead to reduced fertilizer inputs without reducing yield (Jalali, 
2007). In the last few decades, geo-statistics has been used extensively to characterize the spatial variability of soil attributes due to its ability of quantifying and reducing sampling uncertainties and minimizing investigation costs (Emery and Ortiz, 2007; Cambule et al., 2014). Geographic information system (GIS) is a powerful tool which helps to integrate many types of spatial information such as agro-climatic zone, land use, soil management etc; to derive useful information (Adornado and Yoshida, 2008). Further GIS generated soil fertility maps may serve as a decision support tool for nutrient management (Iftikar et al., 2010). So the present study was undertaken to assess the status of soil $\mathrm{pH}, \mathrm{EC}$ and OC in different land use systems of Doda district. The GIS soil fertility maps provide clear information on the patterns and trend with respect to individual soil properties. Soil fertility maps along with a ready database of soil information at district level which will benefit the farmers and planners alike and will help in taking location specific dimensions on nutrient management as well as finalizing course contents specific to that area for future capacity building programmes.

\section{Materials and Methods}

A soil survey was conducted at Doda district in the month of April 2016 to assess the soil physico-chemical properties viz., $\mathrm{pH}, \mathrm{EC}$ and OC under different land use systems namely Forest, Barren lands, Agriculture and Horticulture, respectively. Composite surface soil samples were collected at a depth of 0-15 $\mathrm{cm}$ located at a minimum distance of $4-5 \mathrm{~km}$ apart, distributed randomly across whole of the district. The samples were air dried, ground in a pestle-mortar and passed through a $2 \mathrm{~mm}$ stainless sieve for determining various physico-chemical properties of soils of Doda district. Soil $\mathrm{pH}$ of the samples was determined in 1:2.5 soil: water ratio $(\mathrm{w} / \mathrm{v})$ with the help of glass electrode $\mathrm{pH}$ meter
(Jackson, 1973). Electrical Conductivity was estimated in 1:2.5 soil: water suspension with EC meter (Jackson, 1973). Organic carbon was estimated by Rapid titration method (Walkey and Black, 1934). The various points on the global positioning system (GPS) device were marked during the field work from the locations and imported to Arc GIS software. The geographical information system software Arc GIS were used to interpolate the results from the point data to the entire region. Maps concerning the distribution of soil $\mathrm{pH}, \mathrm{EC}$ and $\mathrm{OC}$ were generated by using Geographic Information System and Inverse distance weighting (IDW) technique. The process of digitization and generation of soil maps was carried out with Arc-Gis 10.3 software.

\section{Results and Discussion}

The $\mathrm{pH}$ of the soils under different land use systems ranged from 4.65-7.21 under forest, 6.10-7.90 under barren land, 5.49-7.55 under agriculture and 5.12-7.30 under horticulture. The mean value was 6.28 under forest, 6.93 under barren land, 6.31 under agriculture and 6.24 under horticulture, respectively. The maximum soil $\mathrm{pH}$ was recorded under barren land (7.90) followed by agriculture (7.55), horticulture (7.30) and forest (7.21). Soil pH was moderately acidic ranged from (5.5-6.0) in north-western and eastern areas of Ghat block. More than 90 percent area of the Gandoh block and south-western areas of Ghat block were having slightly acidic soil $\mathrm{pH}$ (6.0-6.5). Northern area of Gandoh, Thathri and western area of Bhaderwah block were having neutral $\mathrm{pH}$ ranged from (6.5-7.0). The northern area of the Bhaderwah block (60 percent area) was having slightly alkaline $\mathrm{pH}$ range (7.0-7.5) as depicted in (Figure 1). Forest land use system showed lowest $\mathrm{pH}$ value (7.21) which can be attributed to acidic nature of decomposing biomass litter while as barren land showed highest $\mathrm{pH}$ value (7.90) 
which may attributed to the accumulation of $\mathrm{CaCO}_{3}$ and salts( Regmi and Zoebisch, 2004). Under temperate type of climate the mineralization process is slow, results in organic matter accumulation which decomposes slowly and helps in lowering the soil $\mathrm{pH}$ due to acid equivalent which may have direct effect on increased soil acidity Pathak et al., (2005). The Electrical Conductivity under different land use systems ranged from 0.08-0.31 under forest, 0.18-0.77 under barren land, 0.11-0.45 under agriculture and $0.10-0.35$ under horticulture (Table 1). The mean value was 0.19 under forest, 0.44 under barren land, 0.26 under agriculture and 0.23 under horticulture respectively. EC was $(<1 \mathrm{dS} / \mathrm{m})$ indicated that all the blocks having non-saline and is safe for plant growth. 80 percent area of the district were having EC range $(0.2-0.3) \mathrm{dS} / \mathrm{m}$. Gandoh block and northern area of thathri block (90 percent area) were having EC range (0.3-0.4) $\mathrm{dS} / \mathrm{m}$ as depicted in (Figure 2).

Table.1 Range and mean of soil physico-chemical properties under different land use systems of Doda district, J\&K

\begin{tabular}{|c|c|c|c|c|c|c|c|c|c|c|c|}
\hline \multirow{2}{*}{$\begin{array}{l}\text { Soil } \\
\text { property }\end{array}$} & \multicolumn{3}{|c|}{ Forest } & \multicolumn{2}{|c|}{ Barren land } & \multicolumn{3}{|c|}{ Agriculture } & \multicolumn{3}{|c|}{ Horticulture } \\
\hline & Min & Max & Mean & Min Max & Mean & Min & Max & Mean & Min & Max & Mean \\
\hline $\mathrm{pH}$ & 4.65 & 7.21 & 6.28 & 6.107 .90 & 6.93 & 5.49 & 7.55 & 6.31 & 5.12 & 7.30 & 6.24 \\
\hline EC & 0.08 & 0.31 & 0.19 & $\begin{array}{lll}0.18 & 0.77\end{array}$ & 0.44 & 0.11 & 0.45 & 0.26 & 0.10 & 0.35 & 0.23 \\
\hline $\mathrm{OC}$ & 0.45 & 1.19 & 0.81 & $0.21 \quad 0.65$ & 0.45 & 0.35 & 0.87 & 0.61 & 0.47 & 0.97 & 0.67 \\
\hline
\end{tabular}

Fig.1 Digital soil fertility maps of soil pH, EC and OC of soils of Doda district, J\&K (Map of pH in soils of Doda District)

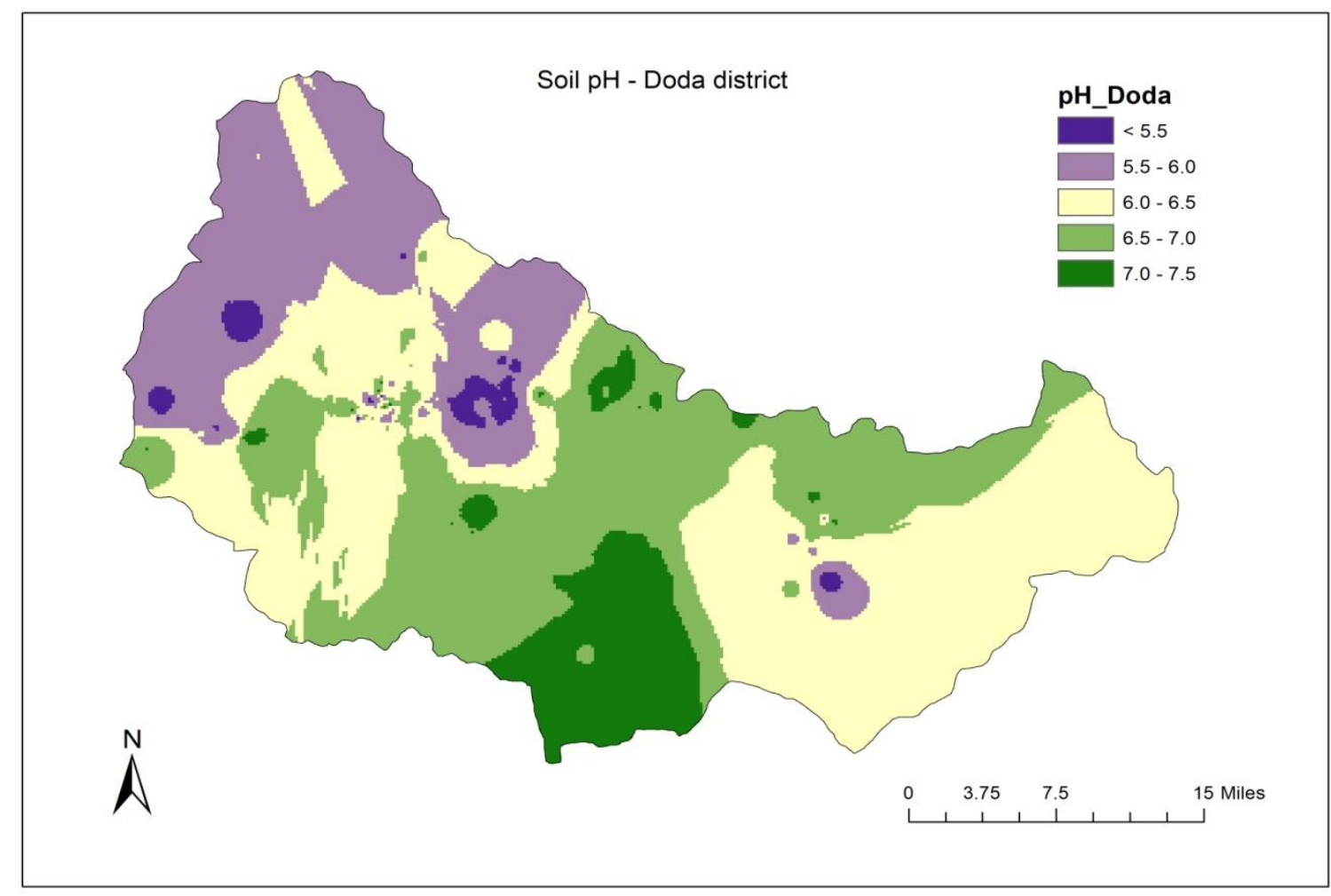


Fig.2 Map of EC in soils of Doda district

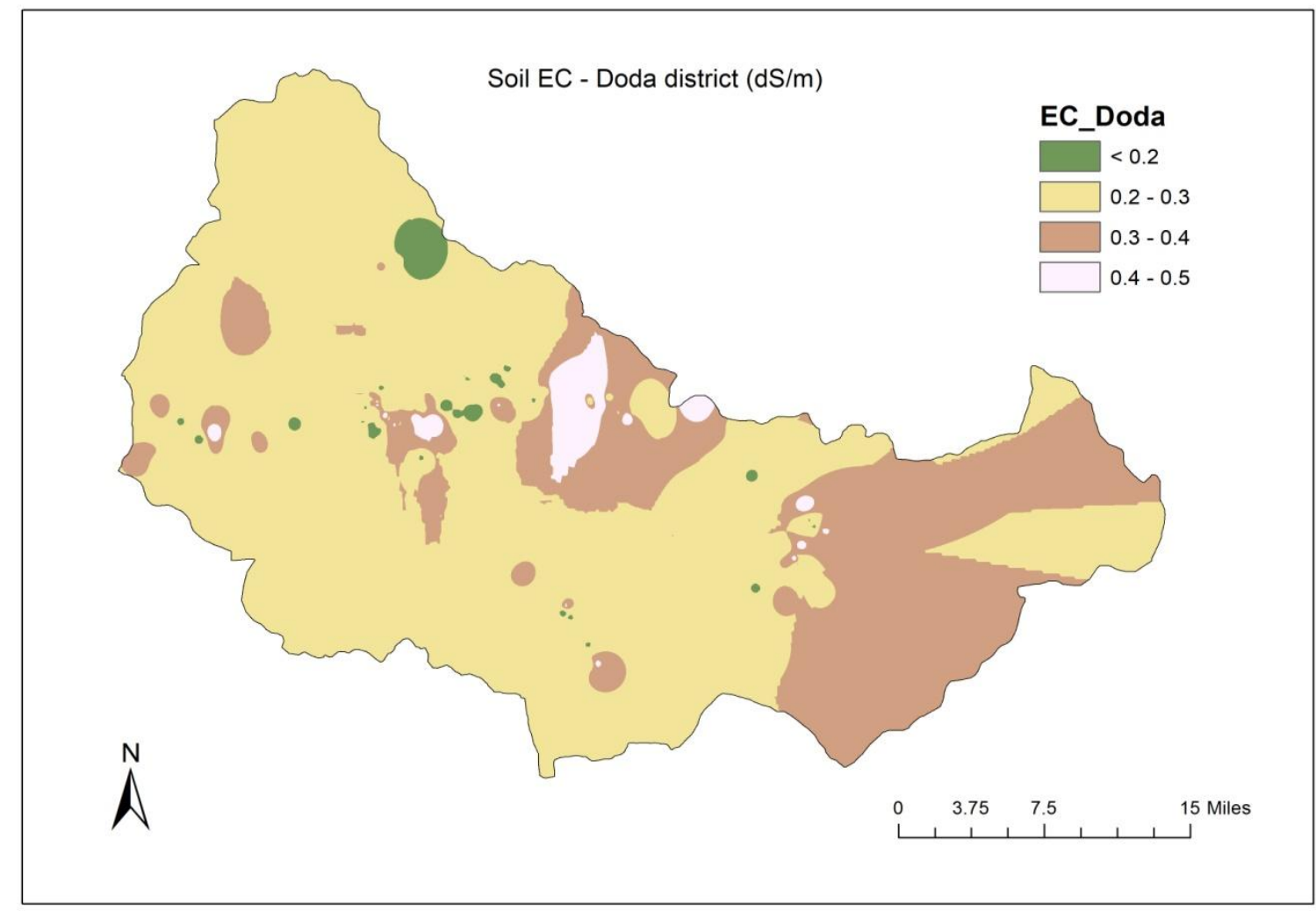

Fig.3 Map of organic carbon in soils of Doda district

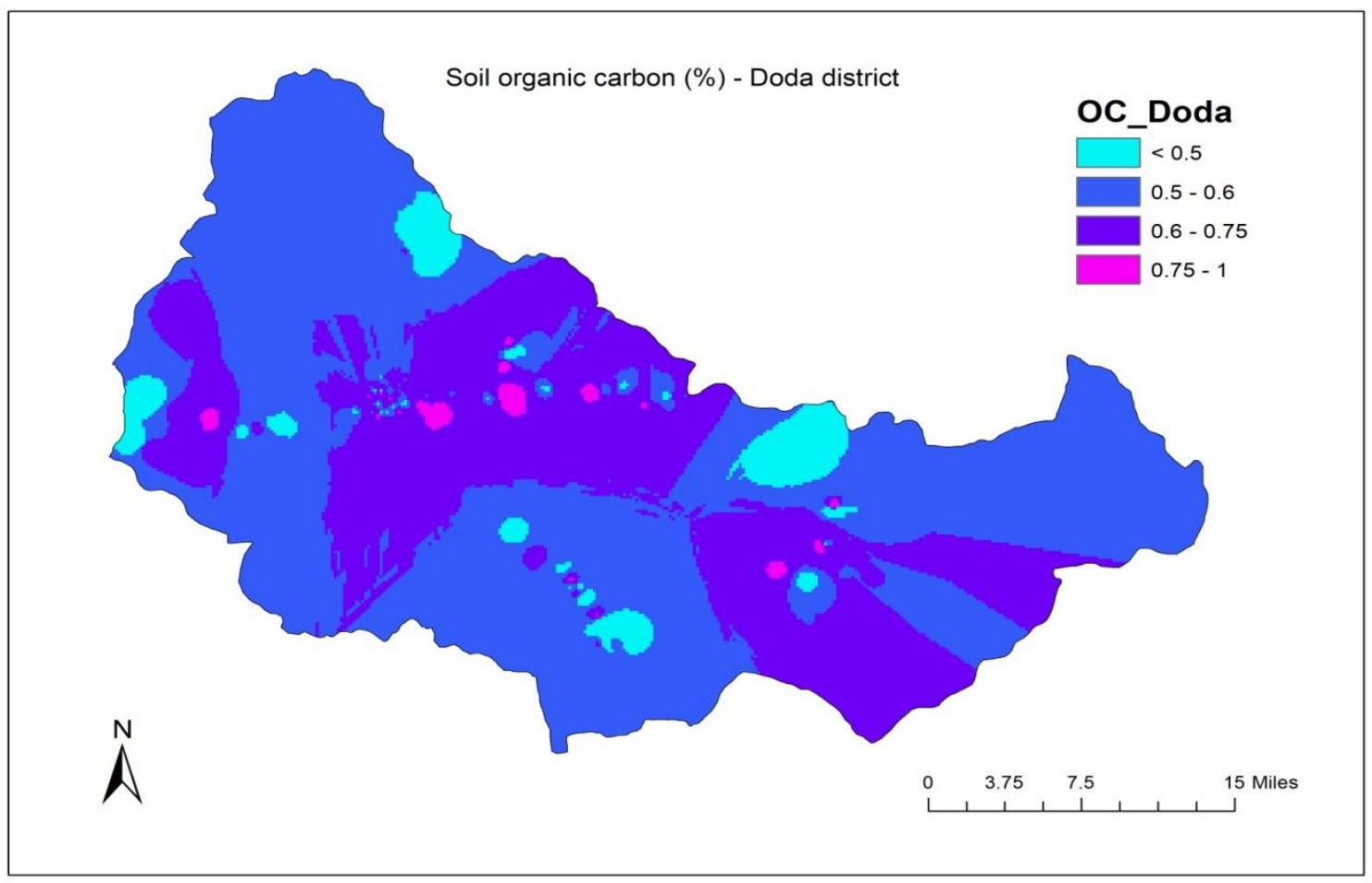


The electrical conductivity in all land use systems of study area was within the safe limit below $1 \mathrm{dsm}^{-1}$ for growing of any crop with lowest mean value in forest. It can be due to accumulation of salts in case of barren lands and high amount of decomposing litter in forest (Kiflu and Beyene, 2013). Because of hilly terrains and high amount of rainfall that cause leaching of salts into sub soil below root zone Abbasi and Rassol, (2007). The OC of the soils were ranged from 0.45-1.19 under forest, 0.21-0.65 under barren land, 0.35-0.87 under agriculture and 0.47-0.97 under horticulture (Table 1). The mean value was 0.81 under forest 0.45 under barren land 0.61 under agriculture and 0.67 under horticulture, respectively. The maximum OC was recorded under forest (1.19), followed by horticulture (0.97), agriculture (0.87) and barren land (0.65). Organic Carbon content was moderate ranged from (0.5-0.6) percent in major portions of Ghat and Bhaderwah blocks and north-eastern side of block Gandoh (70 percent area). OC was moderately high ranged from (0.6-0.75) in central region of district and northern side of block Gandoh.

Less than 1 percent area of Doda was having high OC content (0.75-1.00) as depicted in (Figure 3). Organic carbon content showed a conspicuous variation between the land use systems, the soils of forest area had the highest values of organic carbon content $(1.19 \%)$ and lowest values was observed under barren lands. Higher values of $\mathrm{OC}$ in forest areas can be attributed to high biomass production and lower decomposition rate at higher altitudes Yitbarek et al., (2013) while lower values in agriculture is due to continuous organic matter oxidation subjected to anthropogenic activities Najar et al., (2009). Lower values of OC in barren lands are due to sparse vegetation and no application of organic residues Mansha and Lone, (2013). Accumulation of more OM in forest soils may be due to higher clay content which forms clay-humus complexes and protect the $\mathrm{OM}$ against oxidation and degradation Quiroga et al., (1996).

Thus, it could be concluded from the present study that the soil mapping by using GIS brings out the differences in soil fertility parameters across different land use, climate, and altitude within Doda district and in determining site specific nutrient management to maintain soil health.

\section{References}

Abbasi, M. K., Zafar, M. and Khan, S.R. 2007. Influence of different land-cover types on the changes of selected soil properties in the mountain region of Rawalakot Azad Jammu and Kashmir. Nutrient Cycling in Agroecosystems, 78(1): pp. 97-110.

Adornado, H.A. and Yoshida, M. 2008. Crop suitability and soil fertility mapping using geographic information system (GIS). Agricultural Information Research, 17: 60-68.

Iftikar, W., Chattopadhyaya, G.N., Majumdar, K. and Sulewski, G.D. 2010. Use of village-level soil fertility maps as a fertilizer decision support tool in the red and lateritic soil zone of India. Better Crops 94: 10-12.

Jackson, M.L. 1973. Soil Chemical Analysis. Prentice Hall of India (Pvt.) Ltd., New Delhi.

Jalali M. 2007. Spatial variability in potassium release among calcareous soils of western Iran. Geoderma. 140: 42-51.

Kiflu, A. and Beyene, S. 2013. Effects of different land use systems on selected soil properties in south ethopia. Journal of Soil Science and Environmental Management, 4: 100-107.

Mabit L, Bernard C, Makhlouf $M$ and 
Laverdiere M.R. 2008. Spatial variability of erosion and soil organic matter content estimated from 137Cs measurements and geo-statistics. Geoderma. 145, 245-251.

Mansha, N. and Lone, F.A. 2013. Effect of land use/land cover change on soils of a Kashmir Himalayan catchment-sindh. International Journal of Research in Earth and Environmental Sciences, 1: 2311-2484.

Najar, G.R., Akhtar, F., Singh, S.R. and Wani, J.A. 2009. Characterization and classification of some apple growing soil of Kashmir. Journal of the Indian Society of Soil Science, 57: 81-84.

Pathak, S.K., Singh, S.B., Jha, R.N. and Sharma, R.P. 2005. Effect of nutrient management on nutrient uptake and changes in soil fertility in maize (Zea mays)-wheat (Triticum aestivum) cropping system. Indian Journal of Agronomy, 50(4): pp.269-273.

Quiroga, A.R., Buschiazzo, D.E. and Peinemann, N. 1996. Soil organic matter particle size fractions in soils of the semiarid Argentinian pampas. Soil Science, 161(2): pp.104-108.

Regmi, B.D. and Zoebisch, M.A. 2004. Soil fertility status of bari and khet land in a small watershed of middle hill region of Nepal. Nepal Agricultural Research Journal, 5(38): 124-129

Tesfahunegn G.B, Tamene L and Vlek Paul L.G. 2011. Catchment-scale spatial variability of soil properties and implications on site-specific soil management in northern Ethiopia Soil \& Tillage Research 117:124- 139.

Walkley, A. and Black, C.A. 1934. An examination of the Degtjareff method for determining soil organic matter and a proposed modification of the chromic acid titration method. Soil Science, 37: 29-38.

Yitbarek, T., Gebrekidan, H., Kibret, K. and Beyene, S. 2013. Impacts of land use on selected physicochemical properties of soils of Abobo area, Western Ethiopia. Agriculture, Forest and Fisheries 2: $177-183$.

\section{How to cite this article:}

Tajamul Aziz Alaie and Renu Gupta. 2019. Assessment of Soil pH, EC and OC in Different Land Use Systems of Doda District, J\&K, India. Int.J.Curr.Microbiol.App.Sci. 8(06): 813-818. doi: https://doi.org/10.20546/ijcmas.2019.806.098 